\title{
ISOLASI JAMUR ENDOFIT RIMPANG TEMU KUNCI (Boesenbergia pandurata) DAN UJI AKTIVITAS ANTIOKSIDAN
}

\author{
Deya Apriliana, Wahyu Widayat, Rolan Rusli* \\ Laboratorium Penelitian dan Pengembangan "FARMAKA TROPIS" \\ Fakultas Farmasi Universitas Mulawarman, Samarinda, Kalimantan Timur \\ *email: rolan@farmasi.unmul.ac.id
}

\begin{abstract}
ABSTRAK
Temu kunci (Boesenbergia pandurata) merupakan tanaman dari suku Zingiberaceae) yang memiliki aktivitas biologis salah satunya adalah antioksidan. Jamur endofit merupakan jamur yang terdapat di dalam sistem jaringan tumbuhan seperti daun, bunga, cortex dan akar. Jamur endofit mampu yang menghasilkan metabolit sekunder seperti inangnya. Penelitian ini bertujuan untuk mengisolasi jamur endofit pada rimpang temu kunci yang memiliki aktivitas sebagai antioksidan. Metode isolasi yang digunakan menggunakan teknik sterilisasi permukaan dan penanaman eksplan pada permukaan media Yeast Extract Agar Chloramphenicol (YEAC) kemudian dilakukan pemurnian, karakterisasi, fermentasi dan uji antioksidan dengan metode autografi DPPH. Hasil penelitian diperoleh 2 isolat jamur endofit yang tumbuh pada rimpang temu kunci yaitu genus Aspergilus sp dan Fusarium sp. Ekstrak isolat jamur endofit tersebut memiliki aktivitas antioksidan.
\end{abstract}

Kata kunci : Antioksidan, DPPH, Jamur endofit, Temu kunci (Boesenbergia pandurata), YEAC.

\begin{abstract}
Rhizome of Temu kunci (Boesenbergia pandurata) is a type of plant that comes from ginger group (Zingiberaceae) that have a biological activities such an antioxidant. Endophytic fungi can be found in tissues plant such as leaves, flowers, cortex, etc. Endophytic fungi could potentially produce the secondary metabolites the same as its host. The aim of this experiments was to isolate the endhophytic fungi from rhizome of temu kunci (Boesenbergia pandurata) and examine their antioxidant activity. The isolation method used surface sterilization techniques and cultivation of explants on the media surface Yeast Extract Agar Chloramphenicol (YEAC) then purification, characterization, fermentation and test methods autografi antioxidants with DPPH. A total 2 isolates was obtained from temu kunci rhizome and experiments showed that all of the endophitic fungi have antioxidant activity.
\end{abstract}

Keywords: Antioxidant, DPPH, endophyte fungi, Temu kunci (Boesenbergia pandurata), YEAC.

\section{PENDAHULUAN}

Jamur endofit merupakan mikroorganisme yang terdapat di dalam suatu sistem jaringan tumbuhan seperti biji, daun, bunga, ranting, batang dan akar (Noverita, 2009).

Jamur endofit telah dilaporkan dapat menghasilkan berbagai metabolit bioaktif, baik senyawa yang sudah dikenal maupun senyawa baru (Alvin dalam Hartanti, 2015). Strobel dan Daisy (2003) memperkirakan paling tidak ada 1 sampai 4 jenis jamur yang hidup berasosiasi dengan tumbuhan sebagai jamur endofit yang bersifat culturable (bisa ditumbuhkan pada kondisi artifisial). Jamur endofit merupakan mikroorganisme yang 
tumbuh dalam jaringan tumbuhan. Jamur endofit ini memiliki potensi yang besar dalam pencarian sumber-sumber obat baru. Hal ini karena mikroba merupakan suatu organisme yang mudah untuk ditumbuhkan, memiliki siklus hidup yang pendek, dan dapat menghasilkan jumlah senyawa bioaktif dalam jumlah besar dengan metode fermentasi (Agusta, A., 2009).

Rimpang temu kunci (Boesenbergia pandurata) merupakan tanaman yang memiliki aktivitas biologis salah satunya yaitu antioksidan. Kandungan rimpang temu kunci yaitu minyak atsiri, kamfer, sineol dan terpena. Disamping Minyak atsiri, temu kunci mengandung saponin dan flavonoid (Syamsuhidayat, 1991). Pemanfaatan tanaman temu kunci banyak menemui kendala dikarenakan jumlahnya yang terbatas dan siklus hidup tumbuhan yang relatif lama yaitu 1 tahun untuk dibudidayakan (Sudarsono, 2002). Oleh karena itu, memerlukan alternatif dalam proses mendapatkan metabolit tersebut, salah satu cara untuk memproduksi suatu metabolit sekunder adalah dengan memanfaatkan jamur endofit.

Oleh karena itu dalam penelitian ini dilakukan isolasi, karakterisasi serta uji aktivitas antioksidan jamur endofit yang terdapat pada rimpang temu kunci.

\title{
METODE PENELITIAN
}

\section{Bahan}

Bahan yang diteliti adalah rimpang temu kunci (Boesenbergia pandurata) yang didapatkan dari kota balikpapan, kalimantan timur, alkohol 70\%, $\mathrm{NaOCl} 5,25 \%$, medium yeast ekstrak agar (Merck), medium potatoes dextrose agar (Merck) kloramfenikol, gliserin, kloroform, metanol, kertas saring, DPPH dan Kromatografi Lapis Tipis (Si-gel 60 $\mathrm{GF}_{254}$ Merck).

\begin{abstract}
Alat
Peralatan yang digunakan dalam penelitian ini adalah timbangan analitik, autoklaf, inkubator, cawan petri, gelas kimia, spoid injeksi, hot plate (Stuart), bisturi, Laminar Air Flow (Nuaire), mikroskop kamera, rotary shaker (Stuart), Labu erlenmeyer (Pyrex), Chamber, Mikropipet (Boeco) dan UV portable 254/366nm (UVP).
\end{abstract}

\section{PROSEDUR}

\section{Isolasi jamur endofit}

Isolasi jamur endofit dilakukan dengan beberapa tahap dari sterilisasi eksplan hingga pemurnian. Teknik Isolasi jamur endofit dilakukan menggunakan prinsip sterilisasi permukaan pada tanaman menggunakan suatu desinfektan. Rimpang temu kunci dicuci menggunakan air mengalir hingga kotoran yang menempel bersih dan kering, selanjutnya rimpang direndam dengan alkohol $70 \%$ selama 1 menit, lalu direndam lagi dengan $\mathrm{NaOCl}$ (natrium hipoklorit) 5,25\% selama 3 menit kemudian dibilas dengan aquades steril sebanyak 3 kali. Setelah itu rimpang yang telah disterilisasi permukaannya dikeringkan dengan tissue steril dan dikerjakan secara aseptis di dalam LAF lalu dipotong secara horizontal jaringan rimpang dengan ukuran $\pm 1 \times 1 \mathrm{~cm}$. Kemudian dimasukan medium YEA yang telah ditambahkan dengan antibiotik kloramfenikol $100 \mu \mathrm{g} / \mathrm{mL}$. Sebanyak $\pm 10-15 \mathrm{~mL}$ medium dimasukkan kedalam 3 cawan petri. Lalu dimasukan masing-masing potongan sampel kedalam media dengan pinset steril, diletakkan 3 potong jaringan rimpang temu kunci pada satu cawan petri, pengamatan dilakukan setiap hari hingga tampak koloni jamur yang tumbuh, kemudian diinkubasi selama $7-14$ hari pada suhu ruang $\left(25^{\circ} \mathrm{C}\right)$. 


\section{Pemurnian jamur endofit}

Pemurnian jamur yang telah tumbuh pada permukaan eksplan diinokulasikan berdasarkan perbedaan warna kedalam media baru. Pengamatan dilakukan kembali setelah inkubasi selama 5-7 hari, dan apabila masih ditemukan pertumbuhan koloni yang berbeda maka harus dipisahkan kembali hingga diperoleh isolat murni.

\section{Karakterisasi Isolat Jamur Endofit}

Karakterisasi isolat jamur endofit dilakukan secara makroskopik dan mikroskopik. Makroskopik isolat jamur endofit meliputi warna koloni, warna sebalik koloni, bentuk permukaan, elevasi, tepi dan diameter koloni. Karakterisasi secara mikroskopik ini dilakukan pengamatan menggunakan preparat isolat jamur endofit melalui mikroskop. Metode mikroskopik dilakukan dengan cara menginokulasikan isolat jamur endofit di atas medium YEA yang terdapat di object glass dalam cawan petri, kemudian diinkubasi selama 3-5 hari pada suhu $25^{\circ} \mathrm{C}$, selanjutnya diamati menggunakan mikroskop.

\section{Fermentasi jamur endofit}

Fermentasi jamur endofit dilakukan dengan menggunakan medium PDB (potatoes dextrose broth). Koloni jamur endofit yang tumbuh diambil menggunakan core borer kemudian diambil 3 potongan berukuran $1 \times 1 \mathrm{~cm}$. Potongan tersebut diinokulasikan kedalam Labu erlenmeyer yang berisi medium PDB sebanyak $150 \mathrm{~mL}$ kemudian diinkubasi dengan penggoncangan menggunakan rotary shaker dengan kecepatan 150 rpm selama 14 hari. Hasil inkubasi disaring dengan menggunakan kertas saring untuk memisahkan sel dari media. Sel yang diperoleh di keringkan dengan menggunakan oven pada suhu $50^{\circ} \mathrm{C}$. Setelah kering sel diekstraksi menggunakan pelarut metanol. Ekstrak yang diperoleh dipekatkan menggunakan alat rotary evaporator. Ekstrak metanol miselium digunakan untuk pengujian aktivitas antioksidan.

\section{Uji Aktivitas Antioksidan}

Pengujian aktivitas antioksidan ekstrak jamur endofit menggunakan metode autografi pada plat KLT. Ektrak jamur endofit ditotolkan plat klt kemudian dimasukan ke dalam chamber lalu dielusi menggunakan fase gerak kloroform:metanol 5;5 untuk ekstrak DA 1 dan fase gerak kloroform:metanol 21:5 untuk ekstrak jamur DA2. Kromatogram disemprot menggunakan larutan DPPH 100 ppm dalam metanol pada ruangan gelap. Pengamatan dilakukan dengan memperhatikan pemucatan warna DPPH pada bercak noda dengan latar belakang berwarna ungu pada plat kromatografi lapis tipis.

\section{HASIL DAN PEMBAHASAN}

\section{Isolasi Jamur Endofit}

Jamur endofit yang berhasil diisolasi dari rimpang temu kunci sebanyak 2 isolat jamur. Isolasi jamur endofit dimulai dengan melakukan sterilisasi permukaan rimpang temu kunci, sterilisasi permukaan sampel dilakukan sebelum inkubasi efektif dalam membunuh mikroba epifit atau mikroba yang menempel dibagian permukaan rimpang, sehingga koloni yang tumbuh pada permukaan medium merupakan koloni kapang endofit dari rimpang temu kunci. Sterilisasi dilakukan dengan cara merendam sampel dalam alkohol $70 \%$ dan $\mathrm{NaOCl}$ (natrium hipoklorit) 5,25\%, dimana pengerjaan harus dilakukan secara aseptis di dalam LAF (Laminar Air Flow). Retnosari (2007) menyatakan bahwa alkohol 70\% merupakan antiseptik yang bersifat bakterisida dan kurang efektif terhadap virus dan jamur. Sedangkan $\mathrm{NaOCl}$ merupakan desinfektan yang efektif terhadap bakteri, virus, jamur, parasit dan beberapa spora (Ariyani, 2008). Sehingga dalam proses sterilisasi alkohol dikombinasi 
dengan desinfektan seperti $\mathrm{NaOCl}$ (Agusta, 2009). Sampel yang telah disterilisasi permukaan kemudian dipotong dan diletakkan diatas medium Yeast Extract Agar (YEA) yang telah di tambahkan kloramfenikol yang bertujuan menekan pertumbuhan bakteri yang ikut tumbuh saat isolasi.

\section{Karakteristik Jamur endofit}

Jamur endofit yang berhasil diisolasi dari rimpang temu kunci dikarakterisasi secara makroskopis dan mikroskopis. Hasil Isolasi Jamur endofit dapat dilihat pada gambar 1.

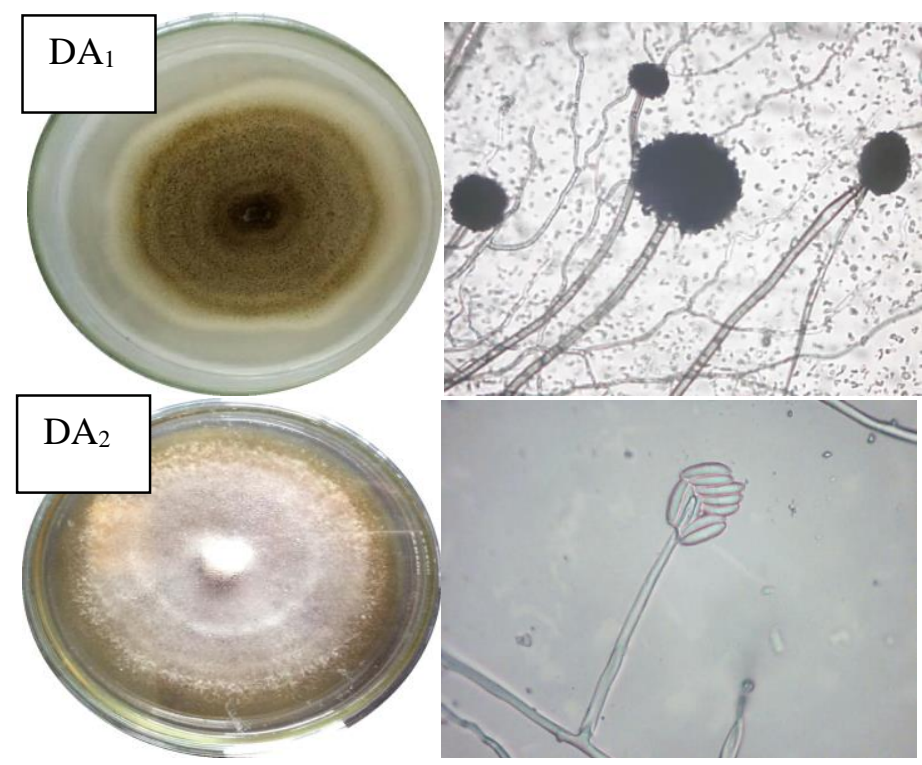

Gambar 1. Makroskopik dan mikroskopik Isolat Jamur Endofit rimpang temu kunci (Boesenbergia pandurata $) . \mathrm{DA}_{1}=$ Aspergilus sp dan $\mathrm{DA}_{2}=$ Fusarium sp.

Hasil isolasi jamur endofit rimpang temu kunci diperoleh 2 jamur. Jamur endofit $\mathrm{DA}_{1}$ memiliki warna hitam dengan tepi putih, warna sebalik putih dengan bentuk circular, elevasi flat dan permukaan yang berbentuk konsentris. Hasil pengamatan mikroskopis jamur endofit $\mathrm{DA}_{1}$ memiliki Sporangium yang berbentuk bulat, dam memiliki sporangiofor. Hasil pengamatan jamur dibandingkan dengan literatur illustrated Genera of Imperfect Fungi jamur $\mathrm{DA}_{1}$ merupakan genus dari aspergillus sp. Aspergillus sp telah banyak diisolasi sebagai endofit dan beberapa di antaranya memiliki aktivitas sebagai antimikroba, seperti yang diisolasi dari tumbuhan Andographis paniculata (Elfita et al., 2011) dan Garcinia mangostana (Elfina et al., 2014).

Jamur endofit $\mathrm{DA}_{2}$ memiliki warna putih dan warna sebalik putih, elevasi flat berbentuk circular dan permukaan seperti kapas. Hasil pengamatan mikroskopis jamur endofit $\mathrm{DA}_{2}$ memiliki konidia , konidiofor, hifa bersepta. Jamur $\mathrm{DA}_{2}$ diduga merupakan genus dari Fusarium.

\section{Aktivitas Antioksidan}

Uji kualitatif terhadap ekstrak metanol jamur endofit dilakukan untuk mengetahui senyawa kandungan ekstrak yang memiliki aktivitas antioksidan. Uji dilakukan dengan kromatografi lapis tipis menggunakan silika gel 60 F254 dan DPPH 100 ppm dalam metanol sebagai pereaksi semprot untuk mendeteksi senyawa yang memiliki kemampuan menangkap radikal bebas suatu senyawa pada ekstrak. Hasil Uji KLT memperlihatkan kedua ekstrak 
jamur endofit $\mathrm{DA}_{1}$ dan $\mathrm{DA}_{2}$ memiliki senyawa aktif antioksidan. Senyawa tersebut akan memberikan warna kuning dengan latar belakang ungu pada plat silika pada sinar tampak. Terbentuknya bercak kuning setelah penyemprotan DPPH disebabkan oleh adanya senyawa yang dapat mendonorkan atom hidrogen di dalam ekstrak jamur endofit sehingga dapat mengakibatkan molekul DPPH tereduksi yang diikuti dengan perubahan warna ungu dari larutan DPPH menjadi kuning bening (Prakash, 2001).

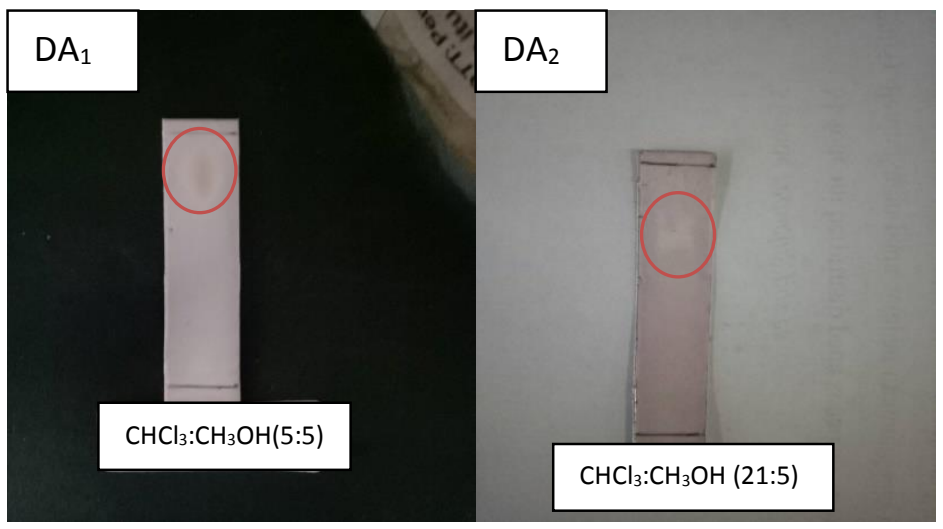

\section{KESIMPULAN}

Hasil isolasi jamur endofit dari rimpang temu kunci (Boesenbergia pandurata) diperoleh 2 isolat jamur endofit yang diduga merupakan jamur dengan genus Aspergillus sp. dan Fusarium sp. Metabolit yang dihasilkan kedua jamur tersebut memiliki aktivitas antioksidan.

\section{DAFTAR PUSTAKA}

Agusta, Andria. 2009. Biologi dan Kimia Jamur Endofit. ITB. Bandung.

Ariyani, M. 2008. Perbedaan Daya Hambat Sodium Hipoklorit dan Kalsium Hidroksida dengan Berbagai Pelarut Terhadap Pertumbuhan Candida albicans. Universitas Sumatra Utara; Medan.

Elfina, D., Martina, A., Roza, R.M. 2014. Isolasi dan karakterisasi fungi endofit dari kulit buah manggis (Garcinia mangostana L) sebagai antimikroba terhadap Candida albicans, Staphylococcus aureus dan Escherichia coli. J. Online Mahasiswa Bidang MIPA, 1:1-10.

Elfita, Muharni, Munawar, Salni, Oktasari, A. 2011. Senyawa antimalaria dari jamur endofitik tumbuhan sambiloto (Andographis paniculata Nees). J. Nature Indonesia 13:123-129.

Hartanti, Dwi. 2015. Isolasi dan Identifikasi Primer Jamur Endofit dari Tumbuhan Obat Nagasari (Mesua ferrea). Pharmacy. 12 (1).

Noverita, 2009. Isolasi dan uji aktivitas antibakteri jamur endofit dari daun dan rimpang Zingiber ottensii. Val. Jurnal Farmasi Indonesia. 4(4). 171-176. 
Prakash, A. 2001. Antioxidant Activity. Medallion Laboratories-Analytical Progress. Volume 19. Nomor 2. Hal 1-4

Retnosari. 2007. Studi Efektivitas Sediaan Gel Antiseptik Tangan Ekstrak Daun Sirih (Piper betle). Majalah Farmasi Indonesia 17(4): 163 - 169.

Strobel GA. 2004. Natural products from endophyti microorganism. Journal of Natural Products . 67:257-268.

Strobel, G. A., and B. Daisy. 2003. Bioprospecting for Microbial Endhophytes and Their Natural Products. Microbiology and Molecular Biology Review. 67. (4). 419-502.

Sudarsono, Gunawan, D., Wahyuono, S., Donatus, I.A., dan Purnomo, 2002, Tumbuhan Obat II, Hasil Penelitian, Sifat-sifat dan Penggunaan, 96-100, Pusat Studi Obat Tradisional, Universitas Gadjah Mada, Yogyakarta.

Syamsuhidayat, S.S. dan Hutapea, J.R. 1991. Inventaris Tanaman Obat Indonesia Edisi I. Badan penelitian dan pengembangan kesehatan Republik Indonesia. Jakarta 